Diabetologia 10, 215-224 (1974)

(C) by Springer-Verlag 1974

\title{
Possible Role of a Microtubular-Microfilamentous System in Glucagon Secretion
}

\author{
V. Leclercq-Meyer, J. Marchand and W.J. Malaisse \\ Laboratory of Experimental Medicine, Free University of Brussels, Brussels, Belgium \\ Received: November 26, 1973, and in revised form: February 25, 1974
}

Summary. The effects of a microfilament-modifier (cytochalasin B), of mitotic spindle-inhibitors (colchicine and vinblastine) and of a microtubule-stabilizer $\left(\mathrm{D}_{2} \mathrm{O}\right)$ on glucagon secretion were studied in vitro, using pieces of pancreas from duct-ligated rats. Cytochalasin B (10 $\mathrm{gg} /$ $\mathrm{ml}$ ) potentiated arginine-induced glucagon release, but was without effect on unstimulated glucagon release. Colchicine $\left(10^{-4} \mathrm{M}\right)$ and vinblastine $\left(10^{-4} \mathrm{M}\right)$ similarly stimulated arginine-induced glucacon release; colchicine did not affect unstimulated glucagon release. Deuterium oxide $(100 \%, \mathrm{v} / \mathrm{v})$ reversibly inhibited arginine-induced glucagon secretion. If it is assumed that the above mentioned drugs specifically interact with microfilaments and microtubules in the $A_{2}$ cells, our results would suggest that a microtubular-microfilamentous system indeed participates in the process of glucagon secretion. The intimate mechanism by which such a system may apparently play both a restrictive and effector role in glucagon release remains, however, to be elucidated.

Key words: Glucagon release, insulin release, pancreatic pieces, microtubular-microfilamentous system, cytochalasin B, colchicine, vinblastine, deuterium oxide, arginine, glucose.
A number of ultrastructural studies have demonstrated, like in a variety of specialized contractile cell types $[1,48]$, the presence of microtubular and microfilamentous structures within the hyaloplasm of several endocrine secretory cells. Such structures have, in particular, been recognized in the pancreatic $\mathrm{B}[2,19$, $29,31,38,39]$ and $A_{2}$ cells $[11,14]$, the follicular [35, $37,49]$ and the calcitonin-releasing $C$ cells [4] of the thyroid gland and the somatotroph of the anterior pituitary gland [15]. Accordingly, it has been suggested that, in these endocrine cells, microtubules and microfilaments might control the intracytoplasmic migration and exocytosis of secretory granules. This is supported by functional investigations, which have demonstrated that agents known to affect the structure or function of microfilaments and microtubules (e.g. cytochalasin B, colchicine, vinblastine, deuterium oxide) influence the release of several hormones. Thus, these agents were found to influence the release of insulin $[7,8,19,20,21,29-32,38,43,46,47,51]$, of thyroid hormones $[35,36,49,50]$, of catecholamines from the adrenal medulla $[9,10,40,45]$, of ACTH and growth hormone from the anterior pituitary gland [18, 41], of posterior pituitary hormones [10] and recently, while this study was in progress, also that of glucagon from the pancreatic $A_{2}$ cell $[11,44,51]$.

The present functional studies were undertaken in order to document the possible participation of microtubules and microfilaments in the process of glucagon release which, like that of insulin and other hormones, apparently involves an emiocytotic extrusion of secretory granules into the extracellular space $[13,14,22$, 27]. The agents studied were cytochalasin $B$, which is thought to induce a disruption of microfilaments without interfering with microtubules [48]; colchicine, which induces a depolymerisation of microtubules through its binding to the protein subunits of these organelles [1]; vinblastine, which causes an aggregation of the microtubular protein in crystalline-like deposits [3]; and deuterium oxide $\left(\mathrm{D}_{2} \mathrm{O}\right)$, which stabilizes the microtubules [16]. It should be emphasized that each of these drugs was used at only one concentration, selected on the basis of its efficiency upon the B cell microtubular-microfilamentous system, as previously assessed by both ultrastructural and biochemical criteria $[29,30]$. A preliminary account of this work has been presented in abstract [24].

\section{Materials and Methods}

\section{Incubation Procedure}

The incubation procedure has been described in detail elsewhere [25]. All incubations were carried out at $37.5^{\circ} \mathrm{C}$ in $2 \mathrm{ml}$ of bicarbonate-buffered medium ( $\mathrm{pH}$ 7.4) containing calcium $(2 \mathrm{mEq} / \mathrm{I})$, bovine albumin $(5 \mathrm{mg} / \mathrm{ml}$; Pentex, fraction $\mathrm{V}$ powder, Miles-Severac, Ltd, Maidenhead, Bershire, England) and equilibrated against a mixture of $\mathrm{O}_{2}(95 \%)$ and $\mathrm{CO}_{2}(5 \%)$. All media were supplemented with glucose $(8.3 \mathrm{mM})$ and "Trasylol"' (833 KIU/ml; kindly supplied by Drs. N. Kiesselbach and G. Wald, Bayer-Wuppertal-Elberfeld, Western Germany, and Bayer-Pharma, Brussels, Belgium).

Pancreatic tissue was removed from female, fed albino rats (body weight: $130-160 \mathrm{~g}$ ) in which the pancreatic duct draining the splenic portion of the pancreas had been ligated for 3 to 4 weeks, according to the technique reported previously [23]. Two rats were used in each experiment, the pancreatic tissue being eut into eight pieces, which were distributed among 8 flasks, so that each flask contained 2 small 
pieces (total weight: 4 to $10 \mathrm{mg}$ ) obtained from 2 different animals. The flasks were incubated for successive periods of $30 \mathrm{~min}$ each, so that each sample of pancreatic tissue served as its own control. No measurement was made during the first period of incubation. Between the various incubation periods, the pieces of pancreatic tissue were not submitted to a washing procedure. However, care was taken to remove any excess of medium carried along with the pieces of pancreatic tissue by delicate contact with a blotting paper.

Two types of experimental design were used. In the first, which we shall refer to as "simple experimental design", all the samples of pancreatic tissue were treated similarly. Two experiments of this type were performed in order to obtain 16 individual results (see Figs. 5, 9). In the second type, referred to as "parallel experimental design", the samples of pancreatic tissue were divided into two or three groups, each group being treated differently. In such a case, four to five identical experiments were performed in order to obtain 12 to 16 individual results for each treatment (see Figs. 2, 3, 4, 6, 7, 8).

\section{Drugs}

Cytochalasin B (Imperial Chemical Industries, Macclesfield, England) was dissolved in dimethylsulfoxide (DMSO, Merck, Darmstadt, Western Germany) and added to the incubation medium so as to reach a final concentration of $10 \mu \mathrm{g} / \mathrm{ml}$. The same volume of DMSO $(10 \mu \mathrm{l} / \mathrm{ml})$ was also added as a control to media containing no cytochalasin B. It had been previously ascertained that, at this concentration, DMSO did not affect insulin release [29, 38]. Colchicine (Sigma Chemical Co., St. Louis, USA) and vinblastine sulfate ("Velbe", Eli Lilly Co., Christiaens, Brussels, Belgium) were used at a concentration of $10^{-4} \mathrm{M}$. In the experiments using $\mathrm{D}_{2} \mathrm{O}(99.9 \%$ purity, Merck, Darmstadt, Western Germany) all $\mathrm{H}_{2} \mathrm{O}$ was replaced by $\mathrm{D}_{2} \mathrm{O}$.

\section{Glucagon and Insulin Determinations}

The glucagon content of the incubation media was estimated by radioimmunoassay [26] and the rate of glucagon release expressed as $\mathrm{pg} / \mathrm{mg}$ wet weight pancreatic tissue/30 min. ${ }^{131} I$-labelled porcine glucagon (CNTS, Paris, France) and purified crystalline beefpork glucagon (kindly donated by Dr. Mary Root, Lilly Research Laboratories, Indianapolis, USA) were used as tracer and standard for these determinations. The properties of the anti-glucagon serum used in the assay have been documented elsewhere [26]. The insulin content of the incubation media was determined by the method of Wright et al. [52] and the rate of insulin release expressed as $\mu \mathrm{U} / \mathrm{mg}$ wet weight pancreatic tissue/30 min. Guinea-pig anti-insulin serum (a gift from Dr. P.H. Wright, University of Indiana, Indianapolis, USA) and ${ }^{125}$ I-labelled bovine insulin were used for these measurements. Purified crystalline rat insulin was used as reference (Lot $R$ 170, a gift from Dr. J. Schlichtkrull, Novo Research Institute, Copenhagen, Denmark). None of the agents used, except $\mathrm{D}_{2} \mathrm{O}$, affected the standard curves in either the glucagon or the insulin assays. The incubation media composed of $100 \% \mathrm{D}_{2} \mathrm{O}$ caused a small upward shift of the glucagon standard curve resulting in a diminished sensitivity (Fig. 1). This shift was taken into account in the estimation of the glucagon content of these media.

\section{Calculations and Presentation of Results}

For each incubation period, the mean values ( \pm SEM) for glucagon and insulin secretion were calculated by pooling the results obtained in separate experiments ( $\mathrm{n}=12$ to 16 ). The effect of any stimulus was assessed individually for each of the samples of pancreatic tissue and expressed as per cent change over the preceding control period. The statistical significance of the observed changes in both glucagon and insulin secretions were analysed using Student's paired $t$ test, according to Snedecor [42]. In some cases, the mean changes in secretion observed in distinct sets of treatments were compared by use of Student's nonpaired $t$ test.

\section{Results}

\section{Control Experiments}

When pieces of pancreatic tissue were incubated for 10 successive periods of $30 \mathrm{~min}$ each in control media (glucose $8.3 \mathrm{mM}$ ) a progressive decrease in the rate of both glucagon and insulin release was observed (Fig. 2). This behaviour confirms previous findings [25]. When arginine $(10 \mathrm{mM})$ was added to the medium during incubation periods 4 and 5, the expected stimulation of both glucagon and insulin release was noticed (Fig. 3). In terms of paired relative change, the response of the $A_{2}$ cell was of smaller amplitude than that of the $B$ cell.

\section{Effects of Cytochalasin $B$}

a. Effect of Cytochalasin $B$ on Arginine-Induced Glucagon Release. The effect of cytochalasin B on arginine-induced glucagon release was studied using a "parallel experimental design" (Figs. 3 and 4). The 8 samples of pancreatic tissue were divided into two groups, the first one being exposed, during incubation periods 4 and 5 , to a $10 \mathrm{mM}$ arginine stimulus alone, and the second one being exposed to $10 \mathrm{mM}$ arginine and $10 \mu \mathrm{g} / \mathrm{ml}$ cytochalasin $\mathrm{B}$.

Fig. 4 illustrates the results which were obtained in the presence of arginine and cytochalasin B. For the sake of comparison, the results of the corresponding control experiment (see Fig. 3) are reported on the graph by the dotted lines. During control periods 2 and 3 , there was no significant difference in both glucagon and insulin outputs between the two experimen- 
tal groups. However, cytochalasin B clearly potentiated the response of the $\mathrm{A}_{2}$ cell to arginine. Thus, the arginine-induced increment in glucagon release averaged $+55 \pm 10($ period 4$)$ and $+40 \pm 10 \%($ period 5$)$ in the absence of cytochalasin $\mathrm{B}$, compared with +147 $\pm 22($ period 4$)$ and $+179 \pm 24 \%$ (period 5$)$ in the presence of the mould metabolite. Using the nonpaired $t$ test, the enhancing effect of cytochalasin B proved to be highly significant $(P<0.001)$ in both periods 4 and 5 .

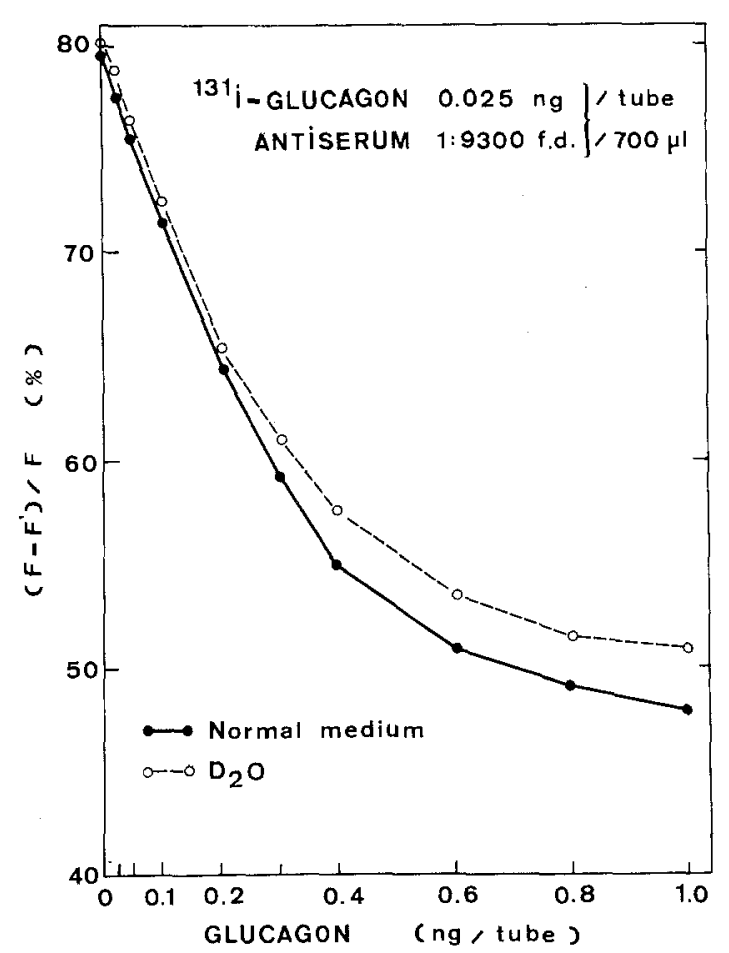

Fig. 1. Effect of $\mathrm{D}_{2} \mathrm{O}$ on glucagon radioimmunoassay. Determinations for the standard curve were performed in the presence of either normal or deuteriated media (100 $\mu \mathrm{l}$, as in any sample determination), the final volume of the reaction mixture in veronal buffer amounting to $700 \mu l$ per tube. The per cent of "undamaged" ${ }^{131} \mathbf{I}$-glucagon bound to the antibody was calculated from the radioactivity adsorbed on dextran-charcoal respectively in the absence $(\mathrm{F})$ or presence $\left(\mathrm{F}^{\prime}\right)$ of antiserum. Also shown is the final dilution of the anti-glucagon serum. (f.d.)

Cytochalasin B also facilitated arginine-induced insulin release (Fig. 4, lower panel). The arginine-induced increment in insulin output averaged $+237 \pm 36$ (period 4 ) and $+376 \pm 50 \%$ (period 5 ) in the absence of cytochalasin B and $+421 \pm 41($ period 4$)$ and +613 $\pm 78 \%$ (period 5$)$ in its presence. The enhancing effect of cytochalasin B was significant ( $P<0.01$ or less) in both periods 4 and 5 .

When the pieces of pancreas were returned to the normal control media during periods 6 and 7 , the release of both glucagon and insulin rapidly declined
(Fig. 4). However, the output of both hormones from the pieces of pancreas which had been exposed to cytochalasin B remained somewhat higher than that found, at the same time, in pieces never exposed to the mould metabolite. This difference in hormonal output during incubation periods 6 and 7 , which suggests that the facilitating action of cytochalasin $B$ was only partially reversible, failed to achieve statistical significance in the case of glucagon, but was highly significant $(P<0.001)$ in the case of insulin.

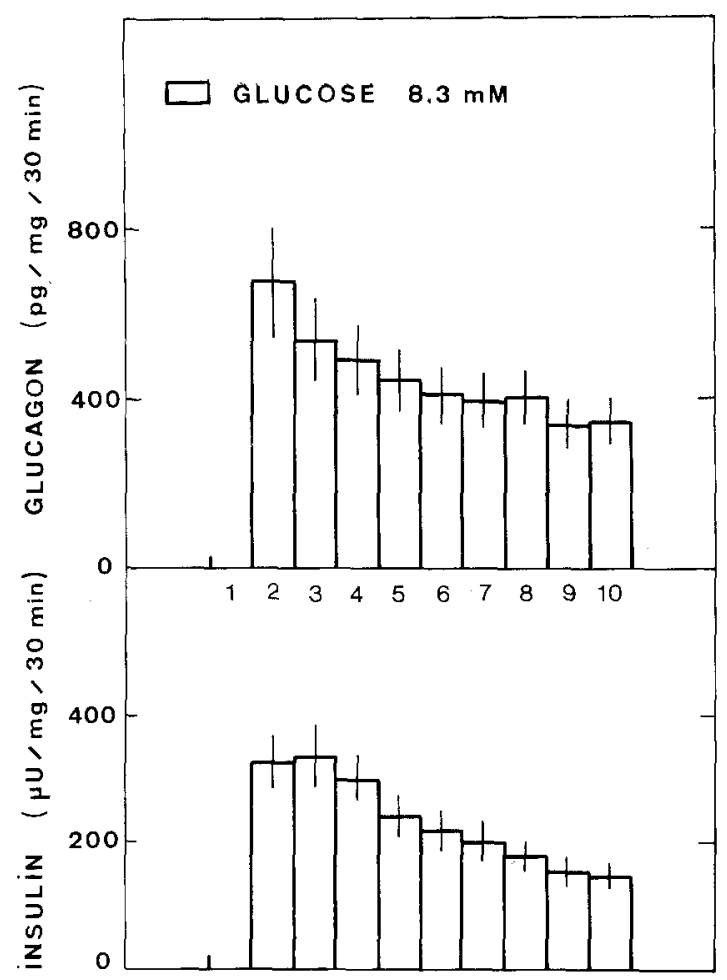

Fig. 2. Release of glucagon and insulin by pieces of pancreas from duct-ligated rats incubated at $8.3 \mathrm{mM}$ glucose for 10 successive periods of $30 \mathrm{~min}$ each. The results were obtained using a "parallel experimental design" and illustrate the control experiment corresponding to Figs. 7 and 8 . They represent the mean ( \pm SEM) of 15 determinations

\section{b. Effect of Cytochalasin B on Unstimulated Glucagon} Release. The effect of cytochalasin B on the unstimulated or even inhibited release of glucagon seen in the presence of glucose $(8.3 \mathrm{mM})$ was investigated using a "simple experimental design" (Fig. 5). Cytochalasin B failed to affect the unstimulated release of glucagon during period 4. Even the modest inhibition of glucagon release observed during period 5 (Fig. 5, upper panel: $5-3:-20 \pm 5 \%$ ) may well merely reflect the normal trend towards a progressive decrease in glucagon release (see Fig. 2). Thus, a steady decline in the rate of glucagon secretion was also observed when the pieces of pancreatic tissue were transferred back to the control media during periods 6 and 7 . 
The release of insulin evoked by glucose $(8.3 \mathrm{mM})$ was enhanced in the presence of eytochalasin $B$, and progressively returned to its control value after removal of the mould metabolite (Fig. 5, lower panel).

\section{Effects of Colchicine and Vinblastine}

a. Effects of Colchicine and Vinblastine on ArginineInduced Glucagon Release. These studies were performed using a "parallel experimental design". The 8 samples of pancreatic tissue were divided into two

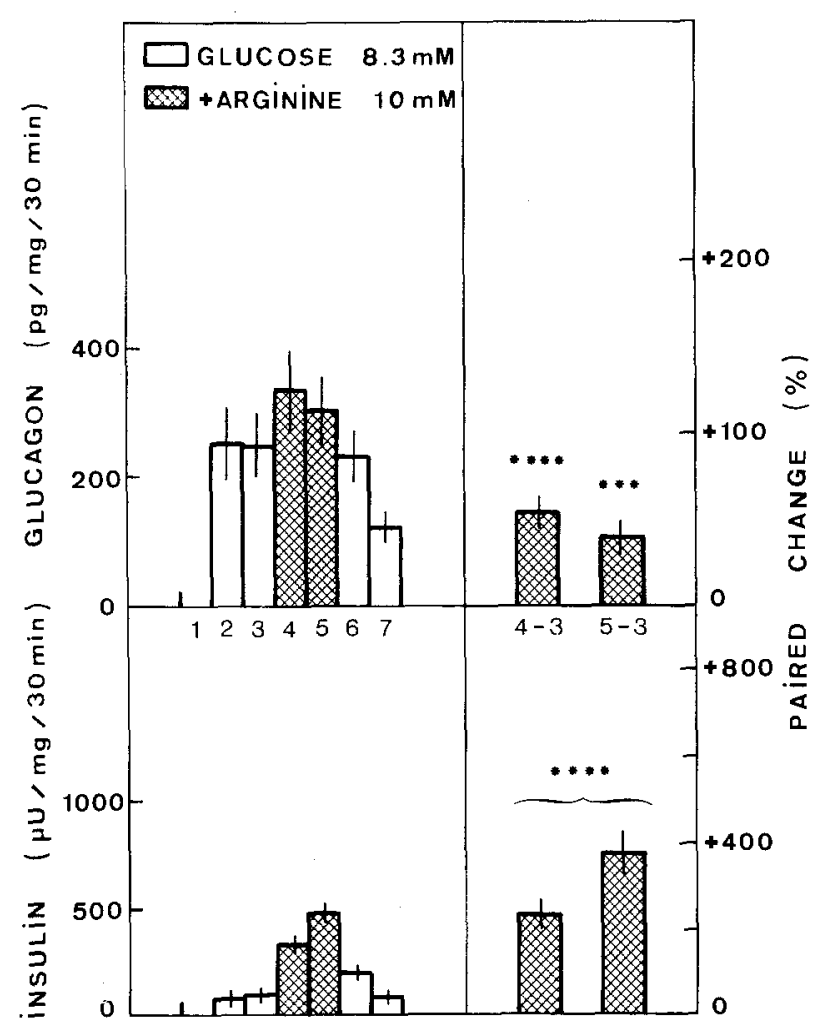

Fig. 3. Effect of a $10 \mathrm{mM}$ arginine stimulus, applied during incubation periods 4 and 5 , on the release of glucagon and insulin. The results were obtained using a "parallel experimental design". They illustrate the control experiment corresponding to Fig. 4. Therefore, DMSO $(10 \mu \mathrm{l} / \mathrm{ml})$ was also present in the incubation media during periods 4 and 5 . The absolute rates of secretion measured during incubation periods 2 to 7 are shown in the panel to the left, and the paired changes in hormonal output induced by arginine are shown in the panel to the right. The results represent the mean ( 1 SEM) of 16 determinations. Levels of significance: $* P<0.05 ; * * * P<0.01 ; * * * * P<0.001$

groups. Half of the samples was incubated for 120 to $150 \mathrm{~min}$ in the normal control media and thereafter exposed for $30 \mathrm{~min}$ to arginine $(10 \mathrm{mM})$. The other half of the samples was similarly incubated for 120 to 150 min, but in the presence of either vinblastine or colchicine $\left(10^{-4} \mathrm{M}\right)$ and, thereafter, also exposed to arginine $(10 \mathrm{mM})$. Vinblastine and colchicine were present during the $30 \mathrm{~min}$ stimulatory period. The effect of arginine, expressed in terms of paired changes over the proceding control periods, is illustrated in Fig. 6. Pretreatment of the pancreatic tissue with a mitotic spindle-inhibitor markedly enhanced the glucagon secretory response to arginine. Thus, prior exposure to colchicine enhanced the arginine-induced increment in glucagon release from $+21 \pm 9$ to $+120 \pm$ $25 \%$, while prior exposure to vinblastine augmented the glucagon response to arginine from $+30 \pm 12$ up to $+86 \pm 13 \%$. By non-paired comparison, these

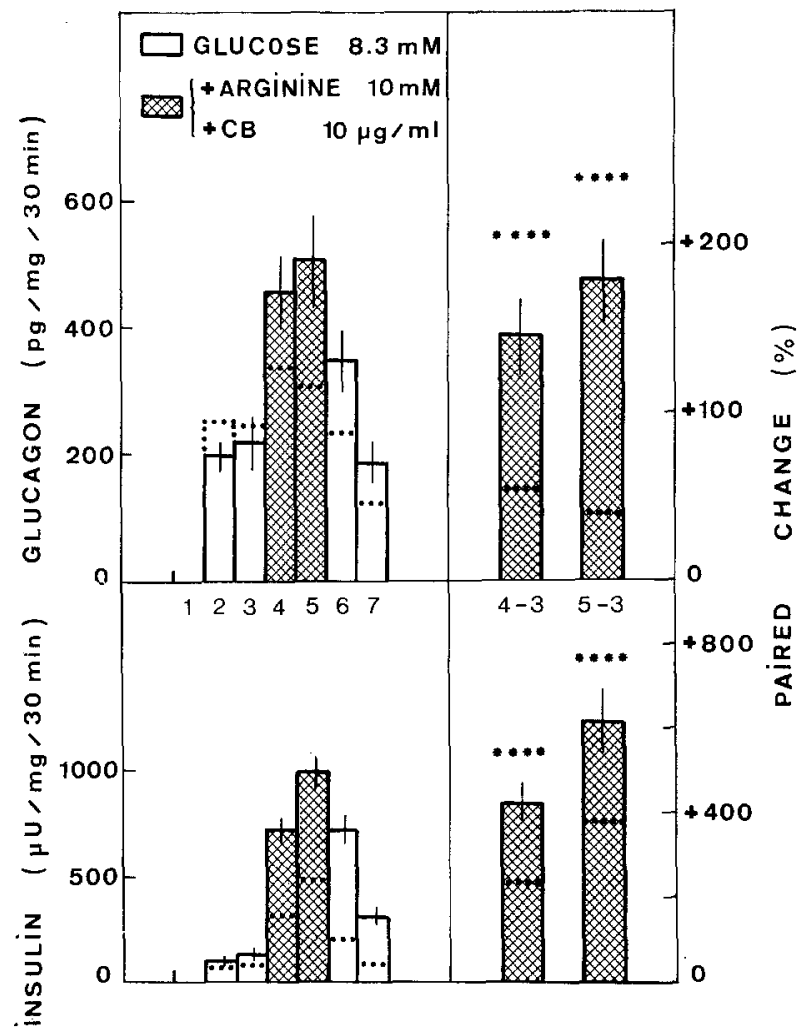

Fig. 4. Effect of a $10 \mathrm{mM}$ arginine stimulus applied, concomitantly with cytochalasin $B(10 \mu \mathrm{g} / \mathrm{ml})$, during incubation periods 4 and 5 , on the release of glucagon and insulin. The results were obtained using a "parallel experimental design". For the sake of comparison, the control values illustrated in Fig. 3 are reported on the graph by the dotted lines. Number of determinations and levels of significance as for Fig. 3

facilitating effects proved to be significant in the case of both colchicine $(P<0.001)$ and vinblastine $(P<$ 0.01 ).

As shown in Fig. 6 (lower panel), the secretory response of the $B$ cell to arginine was partially inhibited in pancreatic tissue pretreated with a mitotic spindleinhibitor. Colchicine reduced the arginine-induced increment in insulin output from $+532 \pm 83$ to $+182 \pm$ $30 \%$; vinblastine reduced the increment from $+298 \pm$ 51 to $+196 \pm 23 \%$. Once again, the inhibitory effect of mitotic spindle-inhibitors proved to be significant, when tested by non-paired comparison. 
b. Effects of Colchicine on Unstimulated Glucagon Release. These experiments were performed using a "parallel experimental design". The 8 samples of pancreatic tissue were divided into three groups. The first group (3 samples) was incubated during 10 successive periods of $30 \mathrm{~min}$, each in the normal control media; the results obtained in this group are shown in Fig. 2. The second group (3 samples) was incubated in the normal control media during incubation periods 1 to 3 and exposed to colchicine $\left(10^{-4} \mathrm{M}\right)$ during incubation

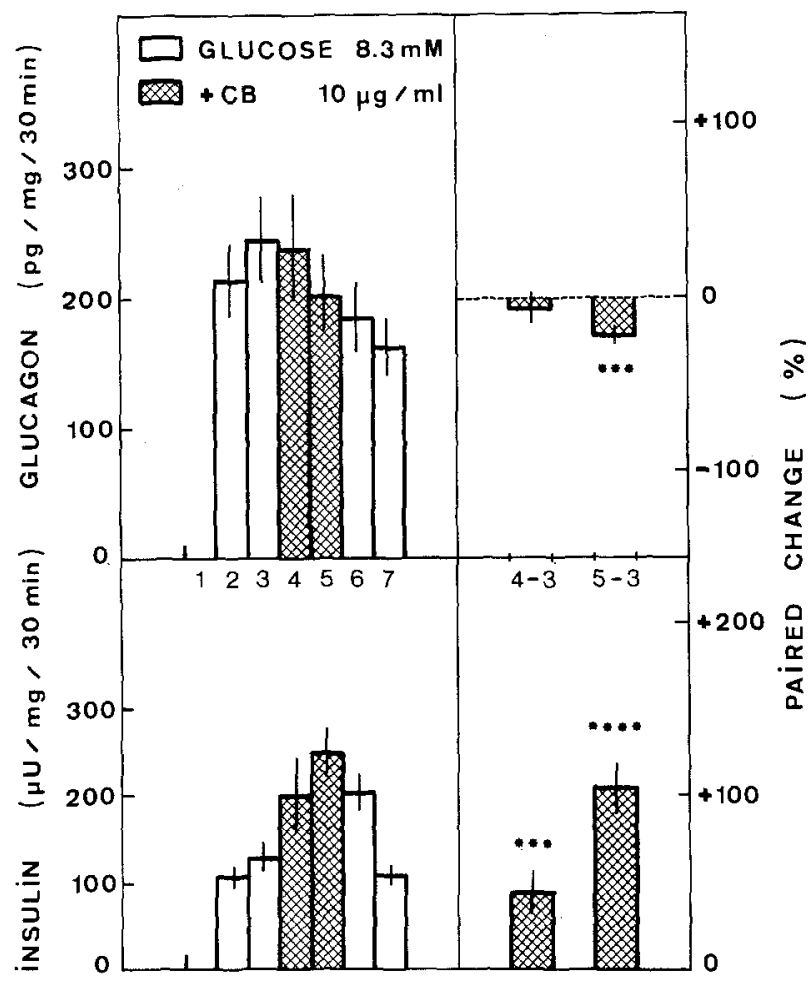

Fig. 5. Effect of cytochalasin $B(10 \mu \mathrm{g} / / \mathrm{ml})$, added to the media during incubation periods 4 and 5 , on the release of glucagon and insulin at $8.3 \mathrm{mM}$ glucose. The results were obtained using a "simple experimental design" and represent the mean ( \pm SEM) of 16 determinations. Levels of significance as for Fig. 3

periods 4 to 10 (Fig. 7). The third group (2 samples) was incubated in the normal control media during incubation periods 1 to 3 , exposed to colchicine during periods 4 and 5 , and subsequently returned to the normal control media during incubation periods 6 to 10 (Fig. 8). Five experiments were performed in order to obtain 15 individual results for the first and the second group, and 10 for the third.

As shown in Fig. 7, almost identical rates of glucagon release were observed during periods 4 to 10 , whether in the presence or absence of colchicine, indicating that colchicine had no influence on unstimul- ated (or even glucose-suppressed) glucagon release. Likewise, the addition of colchicine for only $60 \mathrm{~min}$ (periods 4 and 5) had no significant effect on the decreasing pattern of glucagon release normally observed in the present system (Fig. 8).

Surprisingly, prolonged exposure to colchicine did not inhibit, but actually enhanced, the release of insulin at the $8.3 \mathrm{mM}$ glucose concentration (Fig. 7, lower panel). By non-paired comparison the difference between control (Fig. 2) and experimental (Fig. 7) data

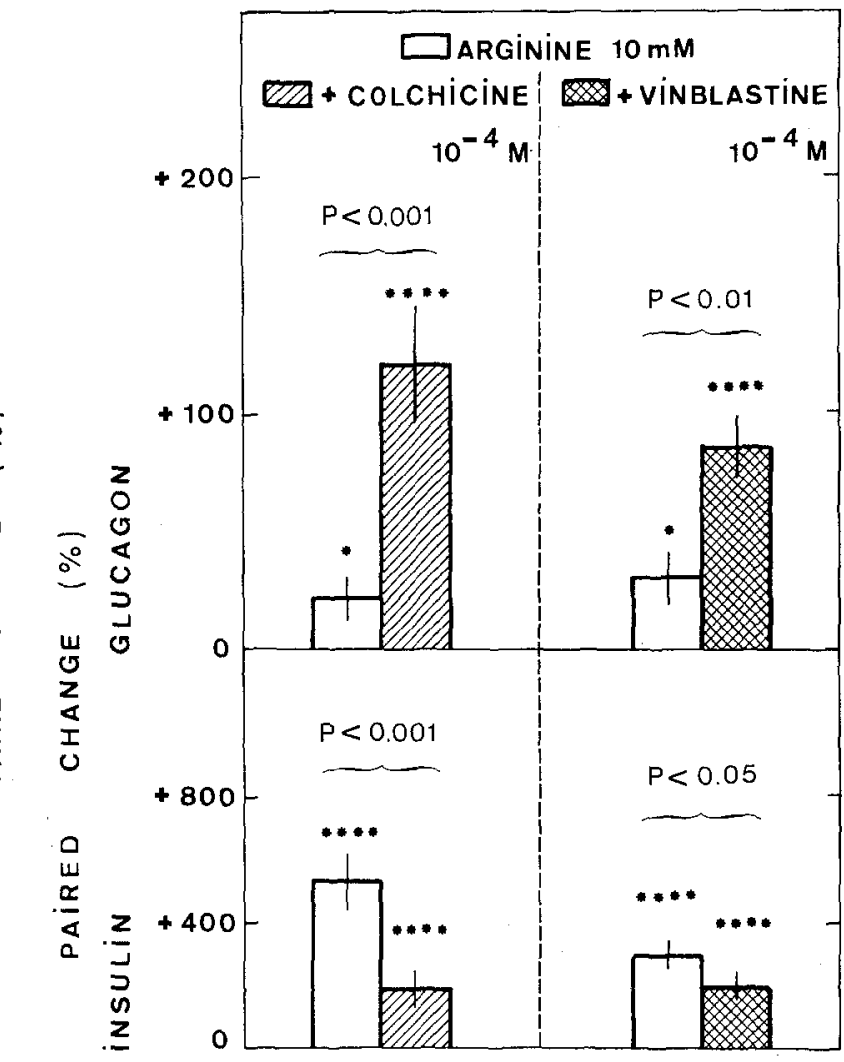

Fig. 6. Effect of arginine $(10 \mathrm{mM})$ on the release of glucagon and insulin in the absence or presence of colchicine and vinblastine at $8.3 \mathrm{mM}$ glucose. The arginine stimuli were applied after $150 \mathrm{~min}$ (colchicine experiments) or $120 \mathrm{~min}$ (vinblastine experiments) of incubation. The columns represent the arginine-induced paired changes in secretion, over the respective preceding control periods, whether in the absence of mitotic spindle-inhibitor (blank columns) or in the presence of either colchicine (hatched columns) or vinblastine (crosshatched columns). The results represent the mean (土SEM) of 16 determinations, with levels of significance as for Fig. 3. The levels of probability $(\mathrm{P})$ indicated on the graph refer to the influence of mitotic spindle-inhibitors, as tested by nonpaired comparison, on the arginine-induced paired changes in hormonal output

was significant ( $P<0.05$ or less) from the 6 th period onwards. As shown in Fig. 8 (lower panel), the enhancing effect of colchicine upon insulin release was even more marked when, after $60 \mathrm{~min}$ exposure to the 
mitotic spindle-inhibitor, the pieces of pancreas were transferred to the control media.

\section{Effects of $D_{2} O$ on Arginine-Induced Glucagon Release}

The effects of $\mathrm{D}_{2} \mathrm{O}$ were investigated using a "simple experimental design" (Fig. 9). Arginine (10 $\mathrm{mM}$ ) was present throughout the incubation procedure and all $\mathrm{H}_{2} \mathrm{O}$ was replaced by $\mathrm{D}_{2} \mathrm{O}$ during periods 4 to 6 . $\mathrm{D}_{2} \mathrm{O}$ significantly inhibited arginine-induced glucagon release, although there was a progressive tendency for

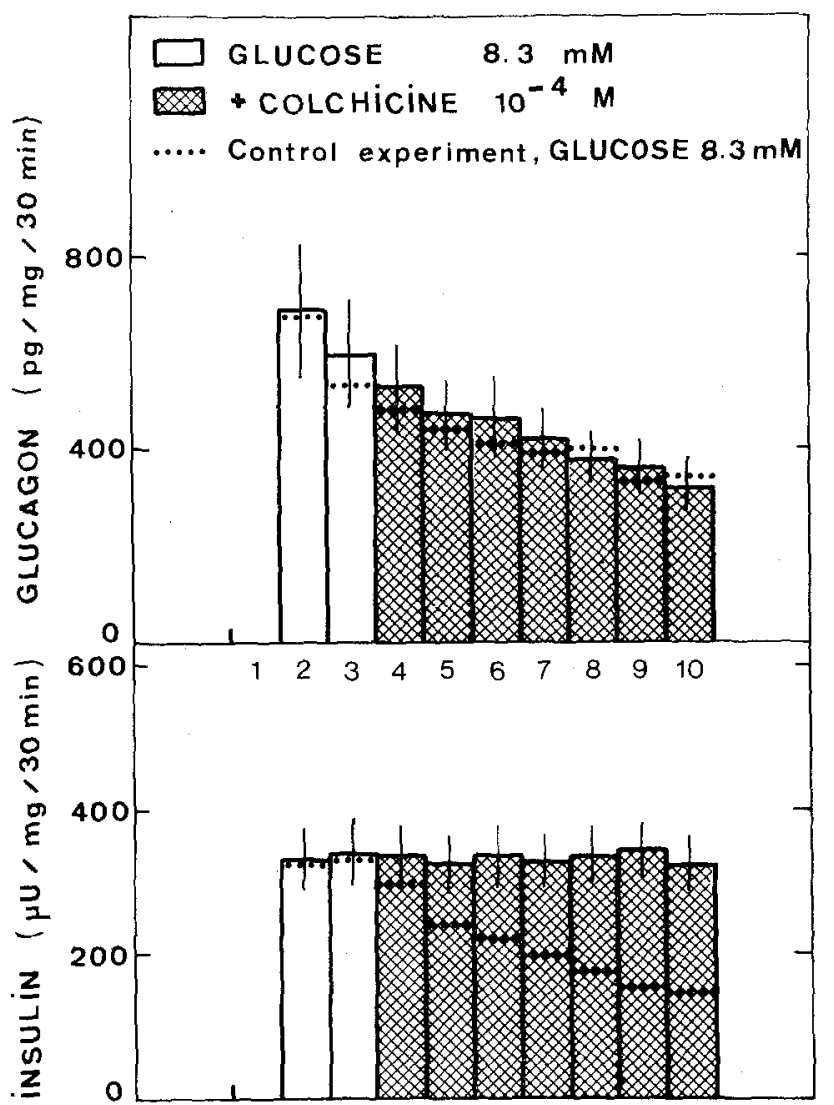

Fig. 7. Glucagon and insulin output at $8.3 \mathrm{mM}$ glucose during prolonged exposure (incubation periods 4 to 10 ) to colchicine $\left(10^{-4} \mathrm{M}\right)$. The results were obtained using a "parallel experimental design" and represent the mean ( \pm SEM) of 15 determinations. For the sake of comparison, the control values illustrated in Fig. 2 are reported on the graph by the dotted lines

glucagon secretion to escape from such an inhibition (Fig. 9, upper panel; 4-3: $-38 \pm 3 \% ; 5-3:-22 \pm$ $4 \% ; 6-3:-18 \pm 4 \%$ ). A striking rebound in glucagon release was observed when the pieces of pancreatic tissue were returned to the $\mathrm{H}_{2} \mathrm{O}$-containing media during incubation period 7 , indicating that the $\mathrm{D}_{2} \mathrm{O}$-induced inhibition of glucagon release was readily reversible (Fig. 9, upper panel; 7-6: $+99 \pm 16 \%$, $P<0.001$ ).

$\mathrm{D}_{2} \mathrm{O}$ also markedly inhibited arginine-induced insulin release (Fig. 9, lower panel; 4-3: $-84 \pm 1 \%$;
$5-3:-81 \pm 3 \% ; 6-3:-80 \pm 3 \%$ ). The inhibitory effect of $\mathrm{D}_{2} \mathrm{O}$ on insulin secretion, like that on glucagon release, was readily reversible (Fig. 9, lower panel; $7-6:+365 \pm 39 \%, P<0.001)$.

\section{Discussion}

The validity of the present model for the measurement of hormonal release by insular tissue has been

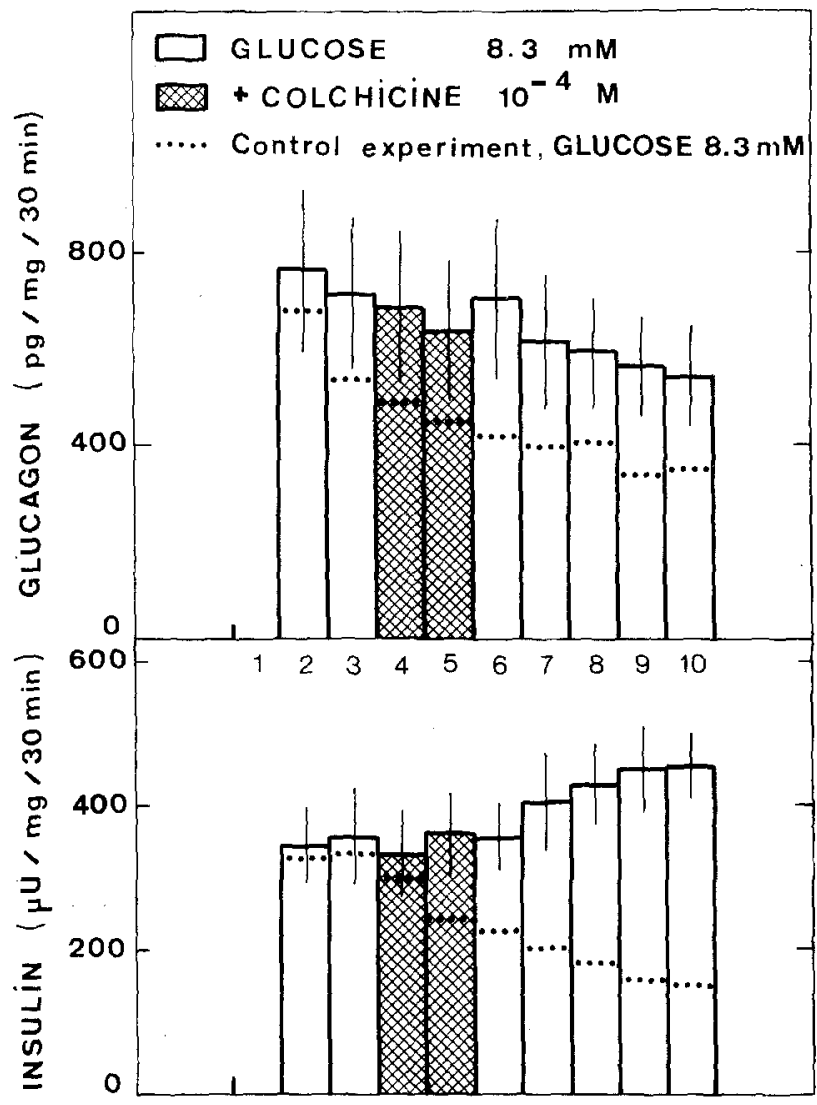

Fig. 8. Glucagon and insulin output at $8.3 \mathrm{mM}$ glucose during short exposure (incubation periods 4 and 5) to colchicine $\left(10^{-4} \mathrm{M}\right)$. The results were obtained using a "parallel experimental design" and represent the mean ( + SEM) of 10 determinations. The control values illustrated in Fig. 2 are reported on the graph by the dotted lines

documented in previous studies [23, 25] and is further assessed by the changes in insulin release here observed. Indeed, the reversible enhancing action of cytochalasin B upon insulin secretion evoked by either glucose (Fig. 5) or arginine (Fig. 4) is in good agreement with previous data collected in isolated islets [20, 29, 38], monolayer cultures of newborn rat pancreas [32, 51] and the isolated perfused rat pancreas $[7,47]$. The inhibition of arginine-induced insulin release by colchicine or vinblastine (Fig. 6) and by $\mathrm{D}_{2} \mathrm{O}$ (Fig. 9) also extends previous findings collected in other in vitro 
systems [19, 21, 30-32, 43]. Even the facilitation by colchicine of insulin release at $8.3 \mathrm{mM}$ glucose concentration (Figs. 7 and 8 ) is consistent with the recent finding that mitotic spindle-inhibitors both facilitate and inhibit insulin release $[8,46]$, the facilitation being masked only under those conditions associated with both a sustained and marked stimulation of insulin release (e.g. at a $16.7 \mathrm{mM}$ glucose concentration) and an extended disruption of the microtubular apparatus (e.g. as a result of prolonged exposure to colchicine).

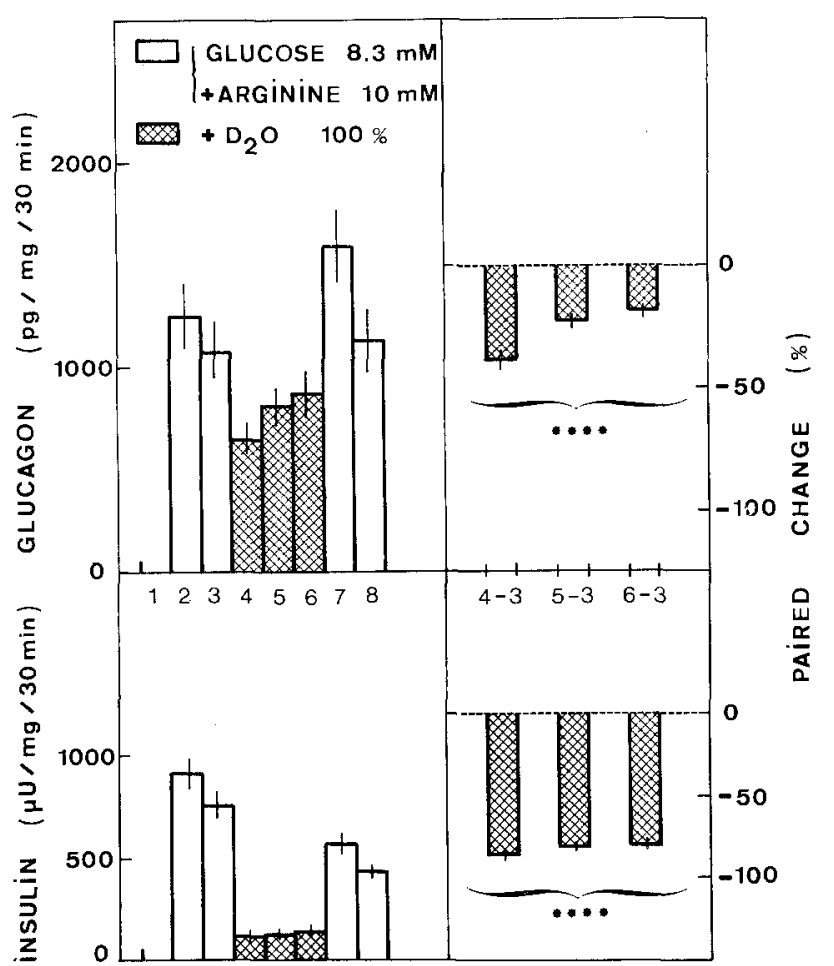

Fig. 9. Effect of $\mathrm{D}_{2} \mathrm{O}$, introduced in the media during incubation periods 4 to 6 , on arginine-induced glucagon and insulin release. Glucose $(8.3 \mathrm{mM})$ and arginine $(10 \mathrm{mM})$ were present throughout the incubation procedure. The results were obtained using a "simple experimental design" and represent the mean ( \pm SEM) of 16 determinations. Levels of significance as for Fig. 3

We have emphasized elsewhere [28] our reasons for believing that the influence upon insulin release of cytochalasin $\mathrm{B}$, colchicine and $\mathrm{D}_{2} \mathrm{O}$ is due to functional alteration of the microtubular-microfilamentous apparatus rather than a non-specific interference with the recognition of secretagogues and subsequent changes in the handling of cations by the B cell.

\section{Effect of Cytochalasin B upon Glucagon Release}

Cytochalasin B reversibly enhanced arginine-induced glucagon secretion (Fig. 4), but failed to affect the unstimulated (or inhibited) release of glucagon at $8.3 \mathrm{mM}$ glucose concentration (Fig. 5), suggesting that the mould metabolite facilitates, but does not initiate, the secretory process in the $A_{2}$ cells. In monolayer cultures of newborn rat pancreas, however, cytochalasin B was found to augment glucagon release at both high and low glucose levels [51].

In our view, the failure of cytochalasin $B$ to enhance glucagon release at $8.3 \mathrm{mM}$ glucose concentration suggests that the effect of the mould metabolite upon the $\mathrm{A}_{2}$ cell secretory activity cannot be solely caused by inhibition of glucose transport, as reported in a variety of other cells $[6,12,17,33,53]$. It is also unlikely that the changes in glucagon release are the consequence of concomitant changes in insulin release. The facilitation of arginine-induced insulin secretion by cytochalasin B would cause, if anything, inhibition rather than augmentation of glucagon release [34]. Although other explanations are conceivable [5], we suggest that the effect of cytochalasin B upon glucagon release is mainly due to its well documented effect on microfilamentous structures. It is thus conceivable, as postulated for insulin release from the B cell [38], that the microfilamentous system of the $A_{2}$ cell participates in the controlled access of glucagon secretory granules to the cell membrane, a process somehow facilitated in the presence of cytochalasin B. However, the confirmation of such an hypothesis awaits further biochemical and ultrastructural studies in the $\mathrm{A}_{2}$ cell. It also remains to be elucidated why cytochalasin $B$ augments insulin and glucagon secretion, but inhibits the release of thyroid hormones $[35,50]$, eatecholamines [10], growth hormone [41] and neurohypophyseal hormones [10] in appropriately stimulated endocrine glands. The contrast between facilitated glucagon (or insulin) release and inhibited growth hormone secretion. is especially intriguing, because both effects were observed with the same concentrations of cytochalasin B $(1$ to $10 \mu \mathrm{g} / \mathrm{ml}$ ) and because hormonal release in both systems is thought to occur through an emiocytotic process $[13,14,15,22,27]$.

\section{Effects of Colchicine and Vinblastine upon Glucagon Re- lease}

After a prolonged exposure to either colchicine or vinblastine, the glucagon secretory response to arginine was enhanced (Fig. 6), while no significant effect of colchicine upon unstimulated glucagon release could be detected (Figs. 7 and 8). The facilitation of arginineinduced glucagon release is in good agreement with the findings of Edwards and Howell in isolated guinea-pig islets of Langerhans [11], but at variance with a preliminary note [44] suggesting that the arginine-induced release of glucagon by the isolated perfused rat pancreas is decreased after 45 to 60 min preperfusion with either colchicine $\left(10^{-4} \mathrm{M}\right)$ or vincristine $\left(10^{-4} \mathrm{M}\right)$. The present failure of colchicine to affect unstimulated glucagon release is also at variance with the findings of Edwards and Howell, who reported that colchicine or vinblastine enhanced unstimulated $(5.5 \mathrm{mM}$ glucose) and inhibited (5.5 mM glucose $+5 \mathrm{mM}$ octanoic acid) glucagon secretion. The explanation for such 
discrepancies remains to be found. In our view, the most pertinent finding is the facilitation of arginineinduced glucagon release by mitotic spindle-inhibitors at a time when arginine-induced insulin release is concomitantly reduced. Once again, we do not believe that the enhanced release of glucagon is the consequence of the reduction in insulin output, since we have previously shown that insulin deficiency, as caused by large amounts of anti-insulin serum, fails to potentiate arginine-induced glucagon release in the present system [25]. As recently observed in the adrenal medulla $[9,10,45]$, the colchicine- or vinblastine-induced changes in hormonal release could be due to pharmacological properties of these drugs, unrelated to their effect on the microtubular apparatus. Nevertheless, it is unlikely, from both previous [11] and the present experiments, that a metabolic rather than biophysical mechanism is responsible for the effects of mitotic spindle-inhibitors on insulin and glucagon secretion. Indeed, whereas the secretory response of the $A_{2^{-}}$and $B$ cell, respectively, to a given metabolic condition (e.g. inhibition of glucose metabolism) are usually inversely related, we purposely used arginine, which, in contrast to most other metabolic substrates, stimulates both insulin and glucagon release. Any alteration in the process of arginine recognition by the pancreatic endocrine cells would be expected, therefore, to affect concomitantly and in the same direction both arginine-induced insulin and glucagon release, which was not the case in our experiments. If one assumes that the present changes in insulin and glucagon secretion are indeed mediated through a disruption of microtubules, our results would suggest that the microtubular apparatus, which in the $\mathrm{B}$ cell is thought to control the oriented intracellular translocation of secretory granules, normally restrains the access of glucagon secretory granules to sites of exocytosis in the $\mathrm{A}_{2}$ cells.

\section{Effect of $\mathrm{D}_{2} \mathrm{O}$ upon Glucagon Release}

$\mathrm{D}_{2} \mathrm{O}$ partially, and reversibly, inhibited argininestimulated glucagon release, with a possible trend for glucagon secretion to progressively and partially escape from the $\mathrm{D}_{2} \mathrm{O}$-induced inhibition (Fig. 9). As already described for insulin secretion $[30,31]$, a rebound in glucagon release was observed at the time of removal of the pancreatic pieces from the deuteriated media.

Because $\mathrm{D}_{2} \mathrm{O}$ is thought to impair microtubular function in endocrine $[30,31,35,36]$ as well as non endocrine cells [16], the inhibitory effect of $\mathrm{D}_{2} \mathrm{O}$ upon glucagon release may appear at variance with the results obtained with mitotic spindle-inhibitors, suggesting a restrictive role for the microtubular apparatus in glucagon release. However, such an apparent inconsistency might well be due to the fact that the stabilizing action of $\mathrm{D}_{2} \mathrm{O}$ upon the microtubularmicrofilamentous system results in an impairment of both the intracellular translocation of secretory granules along the microtubular pathways and exocytosis of those granules already located in close vicinity to the cell web [43].

Once again, confirmation of such an hypothesis is dependent on more knowledge of the biochemical, ultrastructural and functional properties of microtubules in the $\mathrm{A}_{2}$ cell. Meanwhile, the results of the present study are compatible with the idea that, as in a variety of other endocrine cells, a microtubularmicrofilamentous system is intimately involved in the process of glucagon release by the pancreatic $\mathrm{A}_{2}$ cell. It is most intriguing, in this context, that calcium deprivation, which is claimed to arrest insulin release by inactivating the $\mathrm{B}$ cell microtubular-microfilamentous system [28], was recently found to enhance glucagon release by the $A_{2}$ cell [25].

Acknowledgements. This work was supported in part by grants from the Fonds National de la Recherche Scientifique, the Fonds de la Recherche Scientifique Médicale (Brussels, Belgium) and the Contract of the Ministère de la Politique Scientifique within the framework of the Association Contract Euratom-University of Pisa and Brussels.

\section{References}

1. Adelman, M.R., Borisy, G.G., Shelanski, M.L., Weisenberg, R.C., Taylor, E.W.: Cytoplasmic filaments and tubules. Fed. Proc. 27, $1186-1193$ (1968)

2. Bencosme, S.A., Martinez-Palomo, A.: Formation of secretory granules in pancreatic islet B cells of cortisone-treated rabbits. Lab. Invest. 18, 746-756 (1968)

3. Bensch, K. G., Malawista, S. E. : Microtubular crystals in mammalian cells. J. Cell Biol. 40, 95- 107 (1969)

4. Bussolati, G., Monga, G.: A possible role of microtubules in the $\mathrm{C}$ cells secretory mechanism. Experientia 26, 881-883 (1970)

5. Carter, S.B.: The cytochalasins as research tools in cytology. Endeavour 31, 77-82 (1972)

6. Cohn, R.H., Banerjee, S.D., Shelton, E.R., Bernfield, M.R.: Cytochalasin B: lack of effect on mucopolysaccharide synthesis and selective alterations in precursor uptake. Proc. nat. Acad. Sci., (Wash.) 69, $2865-2869$ (1972)

7. Devis, G., Van Obberghen, E., Somers, G., MalaisseLagae, F., Orci, L., Malaisse, W.J.: The effect of cytochalasin $\mathrm{B}$ on the $\mathrm{B}$-cell biphasic response and apparent sensitivity to glucose in the isolated perfused rat pancreas. VIII. Congr. int. Diabotes Fed., Brussels July 1973. Excerpta Medica Foundation ICS 280, 22 (Abstract) (1973)

8. Devis, G., Van Obberghen, E., Somers, G., MalaisseLagae, F., Orci, L., Malaisse, W.J.: Dynamies of insulin release and microtubular-microfilamentous systern. II. Effect of vineristine. Diabetologia, 10, 53-59 (1974)

9. Douglas, W.W., Sorimachi, M.: Colchicine inhibits adrenal medullary secretion provoked by acetylcholine without affecting that evoked by potassium. Brit. J. Pharmacol. 45, 129-132 (1972)

10. Douglas, W.W., Sorimachi, M. : Effects of cytochalasin $B$ and colchicine on secretion of posterior pituitary and adrenal medullary hormones. Brit. J. Pharmacol. 45, 143P-144P (1972) 
11. Edwards, J.C., Howell, S.L.: Effects of vinblastine and colchicine on the secretion of glucagon from isolated guinea-pig islets of Langerhans. FEBS Letters 30, 89-92 (1973)

12. Estensen, R.D., Plagemann, P.G.W.: Cytochalasin $B$ : Inhibition of glucose and glucosamine transport. Proc. nat. Acad. Sci., (Wash.) 69, 1430-1434 (1972)

13. Esterhuizen, A.C., Howell, S.L.: Ultrastructure of the A cells of cat islets of Langerhans following sympathetic stimulation of glucagon secretion. J. Cell Biol. 46, $593-599(1970)$

14. Gomez-Acebo, J., Parrilla, R., Candela, J.L.R.: Fine structure of the A and D cells of the rabbit endocrine pancreas in vivo and incubated in vitro. I. Mechanism of secretion of the A cells. J. Cell Biol, 36, 33-44 (1968)

15. Howell, S.L., Whitfield, M.: Synthesis and secretion of growth hormone in the rat anterior pituitary. $J$. Cell Sci. 12,1-21 (1973)

16. Inoué, S., Sato, H.: Cell motility by labile association of molecules. The nature of mitotic spindle fibers and their role in chromosome movement. J. gen. Physiol. 50, Part 2, 259-288 (1967)

17. Kletzien, R.F., Perdue, J.F., Springer, A.: Cytochalasin A and B. Inhibition of sugar uptake in cultured cells. J. biol. Chem. 247, 2964-2966 (1972)

18. Kraicer, J., Milligan, J.V.: Effect of colchicine on in vitro ACTH release induced by high $\mathrm{K}^{+}$and hypothalamus-stalk-median eminence extract. Endocrinology 89, 408-412 (1971)

19. Lacy, P.E., Howell, S.L., Young, D.A., Fink, C.J.: New hypothesis of insulin secretion. Nature $\mathbf{2 1 9}$ $1177-1179(1968)$

20. Lacy, P.E., Klein, N.J., Fink, C.J.: Effect of cytochalasin $B$ on the biphasic release of insulin in perifused rat islets. Endocrinology 92, 1458-1468 (1973)

21. Lacy, P.E., Walker, M.M., Fink, C.J. : Perifusion of isolated rat islets in vitro. Participation of the microtubular system in the biphasic release of insulin. Diabetes 21, 987-998 (1972)

22. Lazarus, S.S., Shapiro, S., Volk, B.W.: Secretory granule formation and release in rabbit pancreatic Acells. Diabetes 17, $152-160$ (1968)

23. Leclercq-Meyer, V., Brisson, G.R., Malaisse, W.J.: Effect of adrenaline and glucose on release of glucagon and insulin in vitro. Nature, new Biol. 231, 248-249 (1971)

24. Leclereq-Meyer, V., Marchand, J., Malaisse, W.J.: Possible role of a microtubular-microfilamentous system in glucagon secretion. VIII. Congr. int. Diabetes Fed., Brussels July 1973. Fxcerpta Medica Foundation ICS 280, 45 (Abstract) (1973)

25. Leclercq-Meyer, V., Marchand, J., Malaisse, W.J.: The effect of calcium and magnesium on glucagon secretion. Endocrinology 93, 1360-1370 (1973)

26. Leclercq-Meyer, V., Mialhe, P., Malaisse, W.J.: Une méthode de dosage radioimmunologique du glucagon comportant une séparation par le charbon-dextran. Diabetologia 6, 121-129 (1970)

27. Machino, M., Sakuma, H.: Electron microscopy of islet alpha cells of domestic fowl. Nature 214, 808 $809(1967)$

28. Malaisse, W.J.: Role of calcium in insulin secretion. Israel J. med. Sci. 8, 244-251 (1972)

29. Malaisse, W.J., Hager, D.L., Orci, L.: The stimulussecretion coupling of glucose-induced insulin release. IX. The participation of the beta cell web. Diabetes 21, suppl. 2, 594-604 (1972)

30. Malaisse, W.J., Malaisse-Lagae, F., Walker, M.O., Lacy, P.E.: The stimulus-secretion coupling of glucose-induced insulin release. V. The participation of a microtubular-microfilamentous system. Diabetes 20, $257-265(1971)$
31. Malaisse-Lagae, F., Greider, M.H., Malaisse, W.J., Lacy, P.E.: The stimulus-secretion coupling of glucose-induced insulin release. IV. The effect of vincristine and deuterium oxide on the microtubular system of the pancreatic beta cell. J. Cell Biol. 49, $530-535(1971)$

32. Marliss, E.B., Wollheim, C.B., Blondel, B., Orei, L., Lambert, A.E., Stauffacher, W., Like, A.A., Renold, A.E.: Insulin and glucagon release from monolayer cell culture of pancreas from newborn rats. Europ. J. clin. Invest. 3, 16-26 (1973)

33. Mizel, S.B., Wilson, L.: Inhibition of the transport of several hexoses in mammalian cells by cytochalasin B. J. biol. Chem. 247, 4102-4105 (1972)

34. Müller, W.A., Faloona, G.R., Unger, R.H.: The effect of experimental insulin deficiency on glucagon secretion. J. clin. Invest. 50, 1992-1999 (1971)

35. Nève, P., Ketelbant-Balasse, P., Willems, C., Dumont, J.E.: Effect of inhibitors of microtubules and microfilaments on dog thyroid slices in vitro. Exp. Cell Res. 74, 227-244 (1972)

36. Nève, P., Willems, C., Dumont, J.E.: Involvement of the microtubule-microfilament system in thyroid secretion. Exp. Cell Res. 63, 457-460 (1970)

37. Nève, P., Wollman, S.H.: Ultrastructure of the thyroid gland of the Cream Hamster. Anat. Rec. 171, $81-98$ (1971)

38. Orci, L., Gabbay, K.H., Malaisse, W.J.: Pancreatic beta-cell web: Its possible role in insulin secretion. Science 175, 1128-1130 (1972)

39. Orci, L., Stauffacher, W., Beaven, D., Lambert, A.E., Renold, A.E., Rouiller, C.: Ultrastructural events associated with the action of tolbutamide and glibenclamide on pancreatic B-cells in vivo and in vitro. Acta diabet. lat. 6, suppl. 1, 271-374 (1969)

40. Poisner, A.M., Bernstein, J. : A possible role of microtubules in catecholamine release from the adrenal medulla: effect of colchicine, vinca alkaloids and deuterium oxide. J. Pharmacol. exp. Ther. 177, 102 108 (1971)

41. Schofield, J.G.: Cytochalasin B and release of growth hormone. Nature, new Biol. 234, $215-216$ (1971)

42. Snedecor, G.W.: Statistical methods, ed. 5, p. 49. Ames: Iowa State University Press 1956

43. Somers, G., Devis, G., Van Obberghen, E., Ravazzola, M., Orci, L., Malaisse, W.J.: Effoct of deuterium oxide and cytochalasin B on the dynamics of insulin release by the isolated perfused pancreas. VIII. Congr. int. Diabetes Fed., Brussels July 1973. Excerpta Medica Foundation ICS 280, 27 (Abstract) (1973)

44. Soufflet, E., Ballerio, G., Attali, J.R., Boillot, J., Girard, J.R., Assan, R.: Effects of cycloheximide, colchicine and vincristine, on the arginine-induced glucagon secretion, in isolated perfused rat pancreas. VIII. Congr. int. Diabetes Fed., Brussels July 1973. Excerpta Medica Foundation ICS 280, 47 (Abstract) (1973)

45. Trifaró, J.M., Collier, B., Lastowecka, A., Stern, D. : Inhibition by colchicine and vinblastine of acetylcholine-induced catecholamine release from the adrenal gland: an anticholinergic action, not an effect upon microtubules. Molec. Pharmacol. 8, 264-267 (1972)

46. Van Obberghen, E., Somers, G., Devis, G., Ravazzola, M., Orci, L., Malaisse, W.J.: Dual effect of colchicine upon the dynamics of insulin release by the isolated perfused rat pancreas. VIII. Congr. int. Diabetes Fed., Brussels July 1973. Excerpta Medica Foundation ICS 280, 28-29 (Abstract) (1973) 
47. Van Obberghen, E., Somers, G., Devis, G., Vaughan, G.D., Malaisse-Lagae, F., Orci, L., Malaisse, W.J.: Dynamies of insulin release and microtubular-microfilamentous system. I. Effect of cytochalasin B. J. clin. Invest. 52, $1041-1051$ (1973)

48. Wessels, N.K., Spooner, B.S., Ash, J.F., Bradley, M.O., Luduena, M.A., Taylor, E.L., Wrenn, J.T. Yamada, K.M.: Microfilaments in cellular and development processes. Science 171, 135-143 (1971)

49. Williams, J.A., Wolff, J. : Possible role of microtubules in thyroid secretion. Proc. nat. Acad. Sci. (Wash.) 67, $1901-1908(1970)$

50. Williams, J.A., Wolff, J.: Cytochalasin B inhibits thyroid secretion. Biochem. biophys. Res. Comm. 44, $422-425$ (1971)
51. Wollheim, C.B., Marliss, E.B., Blondel, B., Orci, L., Like, A., Renold, A.E.: A-cell function in monolayer cultures of newborn rat pancreas. Diabetologia 9, 96 (Abstract) (1973)

52. Wright, P.H., Malaisse, W.J., Reynolds, I.J.: The assay of partially neutralized guinea-pig anti-insulin serum. Endocrinology 81, 226-234 (1967)

53. Zigmond, S.H., Hirsh, J.G.: Cytochalasin B: Inhibition of D-2-deoxyglucose transport into leucocytes and fibroblasts. Science 176, 1432-1434 (1972)

Prof. Dr. V. Leclereq-Meyer Laboratory of Experimental Medicine Boulevard de Waterloo 115 B-1000 Brussels Belgium 